\title{
Non-Market Household Time and the Cost of Children
}

\author{
Christos Koulovatianos* \\ Department of Economics, University of Vienna, Vienna, A-1010, Austria \\ christos.koulovatianos@univie.ac.at \\ Carsten Schröder \\ Department of Economics, University of Kiel, Kiel, D-24098, Germany \\ carsten.schroeder@bwl.uni-kiel.de \\ Ulrich Schmidt \\ Department of Economics, University of Kiel, Kiel, D-24098, Germany \\ uschmidt@bwl.uni-kiel.de
}

March 10, 2007

\footnotetext{
0* Corresponding author, Department of Economics, Univ. of Vienna, Hohenstaufengasse 9, A-1010 Vienna, Austria. E-mail: christos.koulovatianos@univie.ac.at, Tel: +43-1-427737426, Fax: +43-1-42779374. We are indebted to Irwin Collier and two anonymous referees for offering very detailed guidelines on how to craft this paper. We also thank Timm Bönke, Martin Browning, Katharina Wrohlich, conference participants of the 7th meeting of the RTN project on "The Economics of Ageing in Europe" in Venice, the workshop "Labour Markets and Demographic Change" in Rostock, and participants of the interdisciplinary seminar series at the University of Vienna for useful comments and suggestions. Financial support from the TMR network "Living Standards, Inequality and Taxation," contract No ERBFMRXCT980248, is gratefully acknowledged. Koulovatianos thanks the Leventis foundation and the RTN project on "The Economics of Ageing in Europe" for financial support. Schmidt acknowledges financial support from the Deutsche Forschungsgemeinschaft, contract No. Schm1396/1-1.
} 


\title{
Non-Market Household Time and the Cost of Children
}

March 10, 2007

\begin{abstract}
Raising children demands a considerable amount of parental time, obliging working parents either to further reduce their leisure or to buy child-care services in the market. Parents may face additional opportunity costs upon deciding to participate in the labor market, but these are difficult to measure. Using a survey instrument in Belgium and Germany, we estimate the income compensation needed to maintain family well-being when adults work vs. when they do not enter the labor market. In both countries we find that full-time working parents face extra child costs and require higher labor-market-participation compensation compared to childless adults.
\end{abstract}

Key Words: equivalent income, household well-being, reservation wage, child costs, parental unemployment trap, survey method

JEL Classification: D13, J22, J13, C42, I38, H31 


\section{Introduction}

In a literature survey about how children affect the economic behavior of households Browning (1992, p. 1470-1) noted:

"Every aspect of household economic behavior is significantly correlated with the presence of children in the household. [...] children [...] do play a central role in understanding all facets of household economic behavior."

A particular feature of households with children is that children must be raised by the adults in the household. Child care requires the investment of time, effort, and other resources on the part of adult household members. The constraints faced by adults in this regard are affected by the labor-market-participation status of the adult household members: working adults have less non-market time available for child care and other householdproduction activities than do nonworking adults.

We design a survey instrument in order to estimate the tradeoff between non-market time and household income. This tradeoff is given by the income compensation for a reduction in non-market time required to keep family well-being constant. Empirically, we investigate whether the time/money tradeoff is higher in households with children vs. those without children. Further, we estimate child costs for households with working vs. nonworking adults. Such estimates help in evaluating whether transfers to reduce child poverty are equitable across different household types. Examining whether children affect labormarket-participation compensation enables us to evaluate whether tax allowance policies that reward working parents create sufficient work incentives to move parents out of an unemployment/poverty trap (for example, see Brewer (2001), who discusses related policies in the US and the UK). 
Econometric approaches such as this suggested in Apps and Rees (2001) specify demand systems in order to estimate child costs in different household types from consumption and time-use data. Various factors make this approach challenging. No existing database drawn from the same sample of households contains information about both time use and consumption (Gronau and Hamermesh (2006, p. 3)). Even if such a database existed, its informational content would be limited. For example, the variable 'wage' can be observed only for the sub-sample of working people, making -effectively- a sample selection correction necessary (Wooldridge (2002, p. 552)). Other information is not collected at all: the extent to which household members share goods within the household; the quantity/quality of domestic production; and not least, "who gets what" (Browning (1992, p. 1470)). As a result, to infer prices of domestic goods, including the value of time that adults devote to child-related activities, estimated demand systems depend critically upon (a-priori untestable) exogeneity assumptions, assumptions on within-household sharing rules and functional forms of household production processes, as well as identification restrictions (for example, see Donaldson and Pendakur (2004, 2006) for references concerning restrictions such as "equivalence-scale exactness" used to identify household cost functions, and generalizations they suggest).

Our approach does not rely upon the specification of a theoretical model and thus avoids the need to make modeling assumptions that are a-priori untestable. Our survey method requires respondents to perform a set of evaluation tasks that are directly related to the estimation of child costs in different household types. Similarly with Koulovatianos, Schröder, and Schmidt (2005), our approach relies on the idea that respondents, based on their daily experiences and choices, are capable of providing reliable assessments when asked the following type of question: "Which family-income level can make a household with one working and one nonworking adult with two children achieve the same well-being as a household 
with a nonworking single childless adult and a monthly family income of $\$ 1,000$, in your opinion? What income would one need if instead both adults were nonworking? If both adults were working?" The answers we obtain are equivalent incomes, i.e. disposable family incomes that make the well-being of households with different demographic composition and labor-market-participation status equal. So, the time/money tradeoff is captured by the difference between equivalent incomes of two household types that differ only with respect to the non-market time endowment (NMTE) of adult household members.

We have conducted this survey in two countries, Belgium and Germany, focusing on two types of reductions in NMTE. Starting from a household where all adult members are nonworking, we distinguish: (i) a nonrestrictive reduction in NMTE that leads to a 'traditional' household with one working and one nonworking adult; (ii) a restrictive reduction in NMTE that leads to a situation in which all adults in the household work full time. We find that the time/money tradeoff corresponding to nonrestrictive reductions in NMTE is typically unaffected by the presence of children in the household. On the contrary, in both countries, it is always the case that, in response to a restrictive reduction in NMTE, the time/money tradeoff increases whenever children are present.

As a robustness check, we use regression analysis to estimate child costs relative to an adult, after controlling for economies of household size and also for several personal characteristics of the survey's respondents. Consistently with our results above, child-cost estimates are higher in time-constrained families when compared to households where at least one adult is nonworking. These findings suggest that parents may face additional opportunity costs upon deciding to start working full time, except in one important case: when one of the two nonworking parents decides to go to work. Accordingly, income-taxallowance policies that aim at increasing work incentives need to favor working parents. 
Our results also have broader implications for the building of applied models of the household: as in Apps and Rees (2001), both child-care time and that a household's adults can specialize in market vs. domestic activities need to be modeled explicitly. Apart from providing such general guidelines for modeling, survey-based estimates of equivalent incomes can be used to test the validity of identification restrictions that demand systems impose (for example, Koulovatianos, Schröder, and Schmidt (2005) test the restriction of "generalized equivalence scale exactness"). Furthermore, the 'calibration' line of research on the family, such as Aiyagari et al. (2000) and Greenwood et al. (2005) among others, can benefit from the additional, complementary information that a survey such as ours adds to existing databases. For example, calibration-based models use parameters that cannot be verified empirically due to econometric identification problems (see Gronau (2006)). Survey estimates of equivalent incomes add a 'goodness of fit' criterion to such models and help in assessing the validity of their parameters.

In Section 2 we describe the structure of our survey and the samples we use. In Section 3 we analyze the time/money tradeoffs faced by different family types with an emphasis on a comparison of families with children vs. families without children. In Section 4 we provide estimates of child costs in families with different labor-market-participation status. We discuss the policy relevance of our results in Section 5 and we make concluding remarks in Section 6.

\section{Survey structure and samples}

Our questionnaire consists of three sections, reproduced in the Appendix. The first section gives the respondents an overview and explains the task they are to perform. The second section collects some personal characteristics of the respondents that could possibly affect 
their assessments.

The core questions of our survey are contained in the third section in the form of a 20-cell table (see the Appendix). Each cell corresponds to a particular household type characterized by: (i) number of adults; (ii) number of children; (iii) labor-market-participation status of adults. Moving downwards within each column of the table, the number of children increases (from zero to three children). Moving across rows from left to right, the number of adults increases, from one to two adults, and the labor-market-participation status of each adult also varies between nonworking and working full time. Denoting a nonworking adult by " $N$ " and a full-time working adult by " $W$," the sequence from left to right is, " $N, W, N N, W N$, $W W . "$

The first cell of the questionnaire's table provides a reference income, the disposable monthly income of a reference household, a nonworking single childless adult. All remaining 19 cells are left empty. Respondents are asked to fill them in with after-tax/transfer monthly household incomes that bring all households to the same level of well-being as that of the reference household. Setting these equivalent incomes is the central task that respondents perform in this survey.

Implementing this survey in Belgium and Germany, we asked our respondents explicitly to assume only adults of age 35 to 55 and children of age 7-11 in the households they were asked to consider. Moreover, we were interested in obtaining child-cost estimates for different levels of household well-being. To this end, respondents were provided with three 20-cell tables of the form appearing in the Appendix, each giving a different income for the reference household. The three reference-income levels used in the questionnaire cover a broad range of the disposable-monthly-income distributions of the two countries. The lowest reference income, 500 Euros (EUR), is a proxy for the absolute poverty line (approximately 
the social-security benefit for single-childless adults in both Belgium and Germany). The other two reference incomes are EUR 2000 and EUR 3500.

Our samples consist of 149 respondents in Belgium and 164 in Germany. The questionnaire appeared on the internet and was advertised through web newsletters in both countries. Each respondent was offered the right to participate in a lottery with expected payoff equal to EUR 5. The Belgian sample was collected in April 2002, the German sample in February 2005. Table 1 presents a breakdown of the sample statistics for both countries. The gender distribution of the German sample is relatively male-biased. In both countries, most respondents are between 20-40 years of age and highly educated. These biases are related to the distribution of internet-user attributes.

\section{Equivalent-income profiles and time/money tradeoffs}

\subsection{Descriptive statistics}

Table 2 presents the sample means of the stated equivalent incomes. An immediate observation is that respondents always compensate households for a reduction in NMTE. This is a plausible result, consistent with predictions by theories of the value of time in the literature.

Figure 1 depicts the information given by Table 2. The horizontal axis of each graph represents a household's available NMTE. The value "1" on the horizontal axis is for the case when all adults in the household are nonworking. The value " 0 " means that all adults in the household work full time. For the case of two-adult households in which one adult is working and the other is nonworking, the value " 0.5 " has been assigned. The vertical axis is used for equivalent incomes. Each point plotted represents an average equivalent income, one point for each mixture of household characteristics (given in Table 2). For example, 
consider the entry "WN, $y_{r}=500,2$ children" for Belgium in Table 2 . There we have the average equivalent income of EUR 1614.35 for a couple with two children where one adult is working and the other is nonworking (reference income of EUR 500). This entry is plotted with a "\" symbol which is in the middle of the line labeled "2 children" on the graph "Couples, poor (EUR 500)" in Figure 1.

For any given family type presented in Figure 1 solid lines connect equivalent incomes that correspond to particular levels of NMTE. All solid lines in Figure 1 are downward sloping. This implies that, in both countries, for any given family type, a reduction in NMTE is always associated with a positive income compensation that captures the time/money tradeoff. Figure 1 also shows that as the number of children increases equivalent incomes increase as well.

In each of the twelve graphs of Figure 1, the dashed lines are the "No children" lines shifted upwards in a parallel manner. Differences between slopes of dashed and solid lines reveal differences in the time/money tradeoff between families with children vs. families without children. In both countries, the dashed lines that correspond to couples and a reduction in NMTE from "1" to "0.5," are hardly distinguishable from the solid lines. So, the time/money tradeoff is not affected by the presence of children in the case of a nonrestrictive reduction in NMTE: a transition from " $N N$ " to "WN." On the contrary, when reductions in NMTE are restrictive (transition from " $N$ " to " $W$," or from " $W N$ " to " $W W$ "), solid lines are steeper than dashed lines. This means that the presence of at least one child increases the time/money tradeoff in response to a restrictive reduction in NMTE. 


\subsection{Testing the effect of children on time/money tradeoffs}

Table 3 presents statistical tests of the pattern revealed by the comparison of solid lines and dashed lines in Figure 1. The symbols " $N \rightarrow W, "$ " $N N \rightarrow W N$," and " $W N \rightarrow W W$," denote a transition from a particular constellation of labor-market participation of adults in a household to another constellation. The reduction in NMTE implied by " $N N \rightarrow W N$ " is nonrestrictive, while " $N \rightarrow W$ " and " $W N \rightarrow W W$ " imply restrictive reductions in NMTE. Table 3 presents compensations for specific reductions in NMTE by family type. Differences in these compensations due to the presence of more children reflect differences in the slopes of solid lines in Figure 1.

To test for the effect of children on time/money tradeoffs we investigate the statistical significance of differences in compensations for reductions in NMTE as the number of children increases. For each reference income, at the bottom and in-between each two consecutive columns of descriptive statistics in Table 3, appears a Wilcoxon signed-ranks test statistic and its p-value. It tests the equality of medians that correspond to these adjacent columns. The reason to use Wilcoxon signed-ranks tests instead of pairwise t-tests is that normality is not guaranteed for the errors of the sample means, as this can be seen by the descriptive statistics presented in Table 3. Since the compared observations come from the same sample of respondents they are not independent. For this reason, differences in compensations for reductions in NMTE stated by each individual are tested against a 0-value null hypothesis.

The Wilcoxon tests support the pattern seen in Figure 1. In all cases of restrictive reductions in NMTE children are associated with a stronger time/money tradeoff. In particular, in almost all of these cases the presence of each additional child increases this tradeoff. On the contrary, if the reduction in NMTE is nonrestrictive, children typically do not affect time/money tradeoffs; and if they do, their impact on these tradeoffs is quantitatively 
smaller compared to restrictive reductions in NMTE (this small impact can also be seen in Figure 1).

Our results indicate that time for child-related activities is an essential component of child costs. This is corroborated by research based on time-use data: according to Gronau and Hamermesh (2006, p. 5, Table 1), besides sleep, child care is the second most time-intensive activity after leisure; Bradbury (2005) shows that parents reduce leisure considerably in order to raise their children. Fully working parents ( $W$ and $W W$ ) must either reduce their already limited leisure even more, or buy child-care and other housework services in the market. Traditional households $(W N)$ may still accommodate the time component of child related activities: for example, as in Apps and Rees (2001), the nonworking partner can specialize in these activities. The role of time for child related activities has a general implication for child costs that is consistent with Figure 1 and the tests appearing in Table 3: child costs should be higher in time-constrained families when compared to households in which at least one adult is nonworking. In Section 4 we estimate child costs conditional upon the NMTE of adults and test for this implication.

\section{Labor-market-participation status of adults and child costs}

The regression analysis in this section has two purposes. First, it checks the robustness of the results presented in Section 3 by controlling for respondents' personal characteristics. Second, the regressions provide estimates of child costs conditional upon the labor-marketparticipation status of adults after controlling for household-size economies.

The first regression model that follows Banks and Johnson (1994) and will serve as benchmark is, 


$$
E I R_{i, y}=\left(n_{A}+\alpha_{y} \cdot n_{C}+\beta_{y} \cdot n_{W}\right)^{\theta_{y}}+b_{y} \cdot P E R S O N A L_{i}+e_{i, y} .
$$

The variable $E I R_{i, y}$ is an equivalent-income ratio: it is the equivalent income stated by respondent $i$, divided by the reference income, $y$, of a nonworking single childless adult. The variable $n_{A}$ is the number of adults, $n_{C}$ is the number of children, and $n_{W}$ is the number of working adults in the household. So, $n_{A}, n_{W}$, and $n_{C}$ define the household type. Parameter $\theta_{y}$ controls for household-size economies at reference income $y$. Dividing the stated equivalent income by the corresponding reference income (i.e., using $E I R_{i, y}$ as the dependent variable) will give estimates of parameters $\alpha_{y}, \beta_{y}$, and $\theta_{y}$, that are comparable across different reference incomes, $y$. Parameter $\beta_{y}$ is the compensation for a reduction in NMTE relative to the cost of a nonworking adult. Parameter $\alpha_{y}$ gives the cost of a child relative to a nonworking adult. $\mathrm{PERSONAL}_{i}$ is a set of conditioning variables that comprise the personal characteristics of respondent $i$, listed in Table 1 . Finally, $e_{i, y}$ is the error term.

Columns labeled "Spec. 1" in Table 4 show the regression results for the benchmark specification (1). In both countries and for all reference incomes, $\beta_{y}$ is greater than $\alpha_{y}$. This means that the compensation of an adult for working full time is greater than the cost of a child.

We extend the benchmark regression (1) in order to test the results of Section 3 using the three following regression models:

$$
\begin{aligned}
& E I R_{i, y}=\left(n_{A}+\alpha_{y} \cdot n_{C}+\beta_{y} \cdot n_{W}+\gamma_{y} \cdot n_{C} \cdot D_{W N}+\delta_{y} \cdot n_{C} \cdot D_{F}\right)^{\theta_{y}}+
\end{aligned}
$$

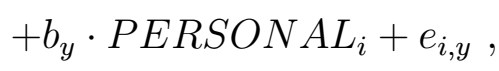

$$
\begin{aligned}
& E I R_{i, y}=\left(n_{A}+\alpha_{y} \cdot n_{C}+\gamma_{y} \cdot n_{C} \cdot D_{W N}+\delta_{y} \cdot n_{C} \cdot D_{F}+\zeta_{y} \cdot n_{A} \cdot D_{W N}+\eta_{y} \cdot n_{A} \cdot D_{F}\right)^{\theta_{y}}+ \\
& +b_{y} \cdot P E R S O N A L_{i}+e_{i, y}
\end{aligned}
$$




$$
\begin{aligned}
& E I R_{i, y}=\left(n_{A}+\alpha_{y} \cdot n_{C}+\gamma_{y} \cdot n_{C} \cdot D_{W N}+\zeta_{y} \cdot n_{A} \cdot D_{W N}+\varphi_{y} \cdot n_{C} \cdot D_{W}+\chi_{y} \cdot n_{C} \cdot D_{W W}+\right.
\end{aligned}
$$

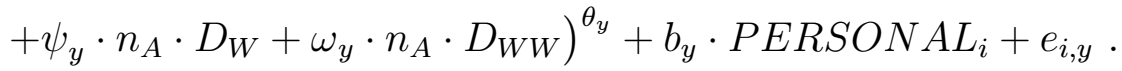

These models introduce the following four dummy variables:

$D_{W N}$ : takes the value 1 for a traditional household ( $W N$ - either with or without children).

$D_{F}: 1$ for either $W$ or $W W$ households (the symbol " $D_{F}$ " denotes the status of full labor-market participation).

$D_{W}: 1$ for $W$.

$D_{W W}: 1$ for $W W$.

Specification (2) extends (1) by distinguishing the effect of a nonrestrictive vs. a restrictive reduction in NMTE on child costs: the effect of a nonrestrictive reduction in NMTE is captured by including the interaction $n_{C} \cdot D_{W N}$, while $n_{C} \cdot D_{F}$ captures the other effect. Specification (3) extends (2) by adding a distinction of the effect of a nonrestrictive vs. a restrictive reduction in NMTE on the costs of adults: the inclusion of $n_{A} \cdot D_{W N}$ and $n_{A} \cdot D_{F}$ (which necessitates dropping $n_{W}$ ). Using $D_{W}$ and $D_{W W}$, (4) further distinguishes the effects of restrictive reductions in NMTE on singles vs. couples.

The estimates of (2) through (4) are presented in columns "Spec. 2" through "Spec. 4" of Table 4. The pattern seen in Figure 1 and tested in Table 3 is reconfirmed: child costs are higher in time-constrained families compared to households in which at least one adult is nonworking. This can be seen by the general pattern that, in most cases, $\gamma_{y}$ is statistically insignificant whereas $\delta_{y}$, or $\varphi_{y}$ and $\chi_{y}$, are significant. In the two exceptions where $\gamma_{y}$ is significantly positive, its value is smaller than the estimates of $\varphi_{y}$ and $\chi_{y}$. 
Two further results are of interest. The estimates of $\zeta_{y}$ are always lower than these of $\eta_{y}$, or $\psi_{y}$ and $\omega_{y}$. This comparison indicates that the traditional household is able to achieve gains from specialization not only with respect to child-related activities (as $\gamma_{y}<$ $\chi_{y}$ implies), but also with respect to other home activities (see Apps and Rees (2001)). Moreover, as in Koulovatianos, Schröder and Schmidt (2005), the estimates of $\theta_{y}$ are seen to fall with reference income, implying that the rich exhibit a higher ability to share within the household. This property has received both theoretical attention and empirical support (see Donaldson and Pendakur $(2004,2006))$.

All reported estimates in Table 4 are controlled for respondents' personal characteristics. Although the inclusion of personal characteristics adds some explanatory power to the regressions (it increases $\bar{R}^{2}$ ), it does not alter the levels of the reported estimates. None of the personal characteristics appeared robust, so they are not reported in Table 4 (these results can be provided by the authors upon request).

Table 5 presents a summary of ranges of child costs based on estimates of (4) compared to estimates by Apps and Rees (2001) for couples. In Apps and Rees (2001, p. 645), the sum of time costs and purchased goods for child-related activities is about $78 \%$ to $98 \%$ of the total consumption of an adult male. These numbers are higher than ours. This difference may be due to: (i) the particular assumptions concerning within-household sharing rules and household-production functions that enable identification of the Apps-Rees demand system; (ii) that, for our survey, respondents were instructed to consider children of age 7-11 years, who may require less child-care time than preschoolers (Bradbury (2005, pp. 20-21)). Nevertheless, our questionnaire can be modified to focus on preschoolers in future research. 


\section{Policy implications for child tax allowances}

Estimating equivalent incomes of families with children contingent upon the labor-marketparticipation status of adults has important implications not only for anti-poverty policies, but also for policies to reduce unemployment. For example, according to Table 2, a single nonworking parent of one child in Germany would need to receive EUR 802 monthly in order to be at the same level of well-being as that of a single childless adult living on social assistance (who receives about EUR 500). These numbers imply equitable social assistance for these two family types.

If this single parent was, instead, working, then the equivalent disposable monthly income is about EUR 1228, according to the estimates of Table 2. This number helps to understand the possibility faced by low-income single parents to fall into an unemployment trap: EUR 1228 corresponds to the 31-st percentile of the German disposable-income distribution of single parents with one child in year 2003 (authors' calculations based on the most recent German Income and Expenditure Survey "Einkommens- und Verbrauchsstichprobe (EVS)"). Thus, to provide work incentives to a single parent of one child, the tax/transfer system needs to ensure that the disposable income of this parent is higher than EUR 1228, conditional upon that she/he works.

In some countries the link between parenthood and work incentives is taken into account. The income transfer systems for low-income families, the "Earned Income Tax Credit" (EITC) in the US and the "Working Families' Tax Credit" (WFTC) in the UK, condition tax credits on the labor-market-participation status of parents. For example, WFTC is higher if families work longer hours in the labor market (at least 30 hours per week) and WFTC is increasing in the number of dependent children (see Brewer (2001) for further details). In some US states EITC also increases with the number of children (see Neumark and Wascher 
(2007, p. 6)).

The results presented here support the practice of the WFTC tax code to distinguish the hours worked by parents, as well as this of the EITC to increase benefits according to the number of children. These distinctions point in the right direction for increasing work incentives for parents. However, the empirical literature concerning the impact of EITC on unemployment is controversial. For example, the empirical literature typically finds evidence of positive effects of EITC benefits on the employment of parents (see Cancian and Levinson (2006, pp. 796-797) for a literature review), while Cancian and Levinson (2006) who focus on Wisconsin, where extra EITC supplements for families with children are provided, have found no such effect. It is therefore of critical importance to estimate the threshold income level that must be exceeded in order to provide sufficient work incentives for parents (such as our estimate of EUR 1228 for single parents with one child in Germany). We believe we have shown how survey-based data can help to identify these thresholds.

\section{Concluding remarks}

Child rearing requires parental time. Time-use data indicate that parents devote a substantial part of their leisure time to raise children. Consequently, working parents must either reduce their already limited leisure even more, or buy child-care and other housework services in the market. This means that parents may face additional opportunity costs upon deciding to start working full time: children in the household can have an effect on the reservation wages of the adults.

We have designed a survey instrument in order to collect everyday people's insights about the magnitude of income compensation required to maintain a constant family well-being when adults are working vs. when they are nonworking. According to our survey respondents 
in Belgium and Germany, labor-market-participation compensation is higher when children are in the household, except for the case when only one of two nonworking parents decides to go to work. Consistently our estimates of child costs are higher in time-constrained families, compared to households where at least one adult is nonworking.

Our study supports that policies channeling extra income-tax allowances to working parents are likely to reduce the possibility that parents find themselves trapped in unemployment and poverty. Examples of such policies are the EITC in the US and the WFTC in the UK.

\section{REFERENCES}

Aiyagari, S., Greenwood, J., and Güner, N., 2000, On the State of the Union. Journal of Political Economy, 108(2), 213-244.

Apps, P., and Rees, R., 2001, Household Production, Full Consumption and the Costs of Children, Labour Economics, 8, 621-648.

Banks, J., and Johnson, P., 1994, Equivalence Scale Relativities Revisited, Economic Journal, 104, 883-890.

Bradbury, B., 2005, Time and the Cost of Children. National Poverty Center Working Paper Series \#05-4.

Brewer, M., 2001, Comparing In-Work Benefits and the Reward to Work for Families with Children in the US and the UK, Fiscal Studies, 22 (1), 41-77.

Browning, M., 1992, Children and Household Economic Behavior, Journal of Economic Literature, 30(3), 1434-1475.

Cancian, M., and Levinson, A., 2006, Labor Supply Effects of the Earned Income Tax Credit: Evidence from Wisconsin's Supplemental Benefit for Families with Three Children, National Tax Journal, 59(4), 781-800.

Donaldson, D., and Pendakur, K., 2004, Equivalent-expenditure Functions and Expenditure-dependent Equivalence Scales, Journal of Public Economics, 88, 175-208.

Donaldson, D., and Pendakur, K., 2006, The Identification of Fixed Costs from Consumer Behavior, Journal of Business and Economic Statistics, 24(3), 255-265. 
Greenwood, J., Seshadri, A., and Yorukoglu, M., 2005, Engines of Liberation, Review of Economic Studies, 72(1), 109-133.

Gronau, R., 2006, Home Production and the Macroeconomy - Some Lessons from Pollak and Wachter and from Transition Russia, NBER Working Paper Series \#8509.

Gronau, R., and Hamermesh, D., 2006, Time vs. Goods: The Value of Measuring Household Production Technologies, Review of Income and Wealth, 52(1), 1-16.

Koulovatianos, C., Schröder, C., and Schmidt, U., 2005, On the Income Dependence of Equivalence Scales, Journal of Public Economics, 89(5-6), 967-996.

Neumark, D., and Wascher, W., 2007, Minimum Wages, the Earned Income Tax Credit, and Employment: Evidence from the Post-Welfare Reform Era, NBER Working Paper Series \#12915.

Wooldridge, J.M., 2002, Econometric Analysis of Cross Section and Panel Data, The MIT Press, Cambridge, Massachusetts, London. 
Table 1. Personal characteristics of respondents

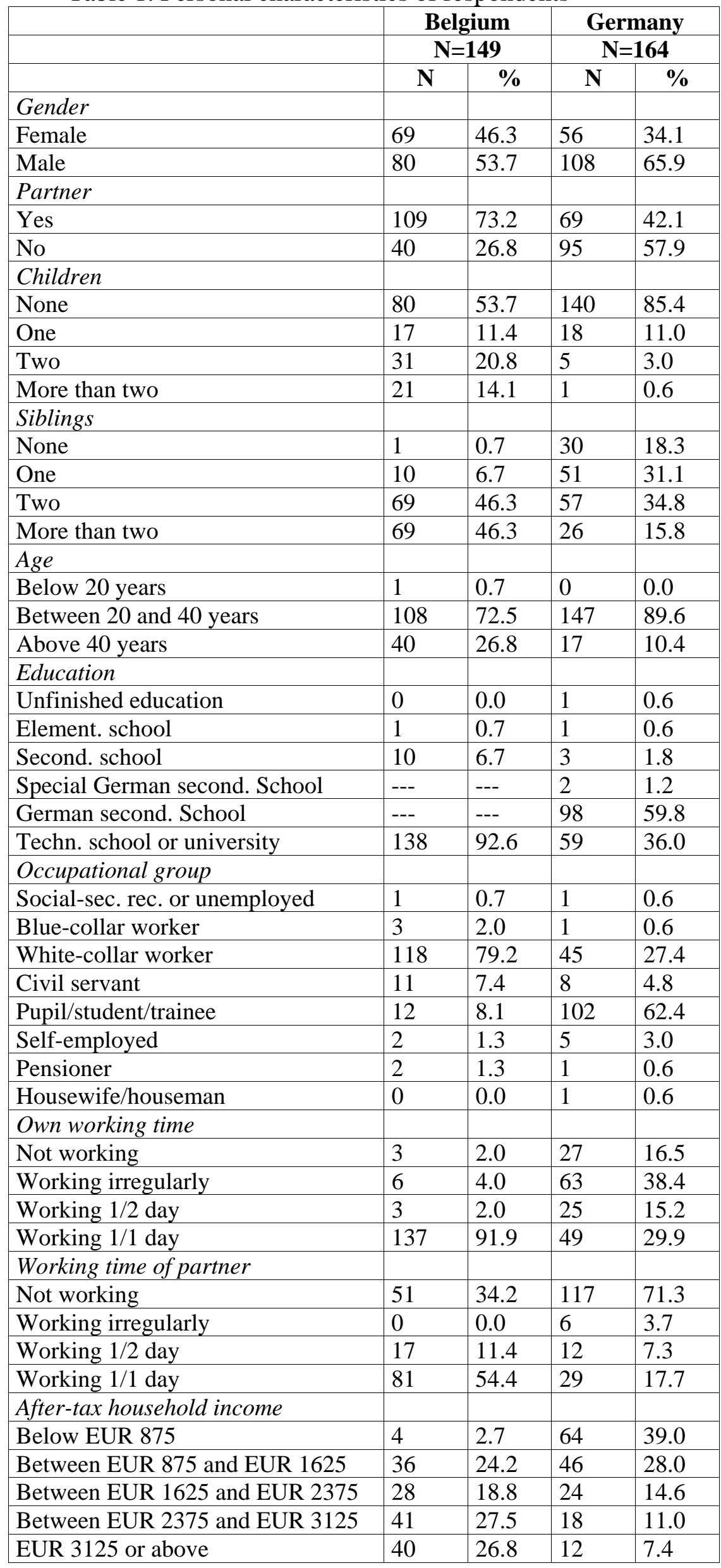


Table 2. Average stated equivalent incomes (values in Euros)

\begin{tabular}{|c|c|c|c|c|c|c|c|c|c|c|c|}
\hline & \multicolumn{5}{|c|}{ Belgium } & \multicolumn{5}{|c|}{ Germany } \\
\hline & & \multicolumn{2}{|c|}{ Singles } & \multicolumn{3}{|c|}{ Couples } & \multicolumn{2}{|c|}{ Singles } & \multicolumn{3}{|c|}{ Couples } \\
\hline$y_{r}$ & & $N$ & $W$ & $N N$ & $W N$ & $W W$ & $N$ & $W$ & $N N$ & $W N$ & $W W$ \\
\hline \multirow{4}{*}{500} & $\begin{array}{c}\text { No } \\
\text { children }\end{array}$ & --- & $\begin{array}{l}803.34 \\
(23.24)\end{array}$ & $\begin{array}{l}879.09 \\
(13.76)\end{array}$ & $\begin{array}{c}1140.21 \\
(31.23)\end{array}$ & $\begin{array}{c}1449.88 \\
(53.21)\end{array}$ & --- & $\begin{array}{l}903.35 \\
(21.66)\end{array}$ & $\begin{array}{l}977.13 \\
(18.63)\end{array}$ & $\begin{array}{c}1314.33 \\
(33.50)\end{array}$ & $\begin{array}{c}1715.85 \\
(53.18)\end{array}$ \\
\hline & $\begin{array}{c}1 \\
\text { child }\end{array}$ & $\begin{array}{c}758.37 \\
(9.45) \\
\end{array}$ & $\begin{array}{l}1089.86 \\
(24.79) \\
\end{array}$ & $\begin{array}{c}1133.79 \\
(20.00) \\
\end{array}$ & $\begin{array}{l}1392.81 \\
(33.78) \\
\end{array}$ & $\begin{array}{c}1765.01 \\
(56.74) \\
\end{array}$ & $\begin{array}{c}802.13 \\
(8.43) \\
\end{array}$ & $\begin{array}{l}1227.90 \\
(25.65) \\
\end{array}$ & $\begin{array}{c}1266.10 \\
(20.52) \\
\end{array}$ & $\begin{array}{l}1603.96 \\
(36.27) \\
\end{array}$ & $\begin{array}{c}2070.58 \\
(55.63) \\
\end{array}$ \\
\hline & $\begin{array}{c}2 \\
\text { children } \\
\end{array}$ & $\begin{array}{l}970.12 \\
(16.80) \\
\end{array}$ & $\begin{array}{l}1327.70 \\
(30.53) \\
\end{array}$ & $\begin{array}{c}1350.72 \\
(26.78) \\
\end{array}$ & $\begin{array}{c}1614.35 \\
(37.39) \\
\end{array}$ & & $\begin{array}{l}1073.41 \\
(16.59) \\
\end{array}$ & $\begin{array}{c}1498.63 \\
(31.90) \\
\end{array}$ & $\begin{array}{l}1522.38 \\
(27.41) \\
\end{array}$ & $\begin{array}{c}1866.16 \\
(4.36) \\
\end{array}$ & $\begin{array}{c}2371.19 \\
(61.40) \\
\end{array}$ \\
\hline & $\begin{array}{c}3 \\
\text { children } \\
\end{array}$ & $\begin{array}{c}1179.53 \\
(24.82) \\
\end{array}$ & $\begin{array}{l}1560.98 \\
(39.79) \\
\end{array}$ & $\begin{array}{l}1570.64 \\
(34.96) \\
\end{array}$ & $\begin{array}{l}1826.42 \\
(42.18) \\
\end{array}$ & $\begin{array}{c}2255.48 \\
(71.41) \\
\end{array}$ & $\begin{array}{l}1323.05 \\
(26.58) \\
\end{array}$ & $\begin{array}{c}1758.69 \\
(40.93) \\
\end{array}$ & $\begin{array}{l}1747.35 \\
(34.96) \\
\end{array}$ & $\begin{array}{c}2102.74 \\
(52.20) \\
\end{array}$ & $\begin{array}{c}2645.58 \\
(70.85) \\
\end{array}$ \\
\hline \multirow{4}{*}{2000} & $\begin{array}{c}\text { No } \\
\text { children }\end{array}$ & --- & $\begin{array}{c}2621.05 \\
(64.76) \\
\end{array}$ & $\begin{array}{c}3096.03 \\
(51.36) \\
\end{array}$ & $\begin{array}{c}3567.15 \\
(89.02) \\
\end{array}$ & $\begin{array}{r}4177.36 \\
(145.19) \\
\end{array}$ & --- & $\begin{array}{c}2829.57 \\
(67.48) \\
\end{array}$ & $\begin{array}{c}3227.29 \\
(57.10) \\
\end{array}$ & $\begin{array}{c}3856.16 \\
(89.18) \\
\end{array}$ & $\begin{array}{r}4718.60 \\
(147.11) \\
\end{array}$ \\
\hline & $\begin{array}{c}1 \\
\text { child }\end{array}$ & $\begin{array}{c}2465.65 \\
(29.81)\end{array}$ & $\begin{array}{c}3158.14 \\
(78.34)\end{array}$ & $\begin{array}{c}3541.10 \\
(71.35)\end{array}$ & $\begin{array}{c}4042.99 \\
(105.57)\end{array}$ & $\begin{array}{l}4743.60 \\
(157.43)\end{array}$ & $\begin{array}{c}2460.37 \\
(36.42)\end{array}$ & $\begin{array}{c}3308.08 \\
(82.82)\end{array}$ & $\begin{array}{c}3628.81 \\
(78.24)\end{array}$ & $\begin{array}{l}4287.35 \\
(109.57)\end{array}$ & $\begin{array}{l}5249.54 \\
(168.85)\end{array}$ \\
\hline & $\begin{array}{c}2 \\
\text { children } \\
\end{array}$ & $\begin{array}{c}2861.60 \\
(54.66) \\
\end{array}$ & $\begin{array}{c}3602.28 \\
(97.20) \\
\end{array}$ & $\begin{array}{c}3935.85 \\
(96.26) \\
\end{array}$ & $\begin{array}{l}4450.42 \\
(127.00) \\
\end{array}$ & $\begin{array}{l}5200.36 \\
(174.53) \\
\end{array}$ & $\begin{array}{r}2812.20 \\
(56.29) \\
\end{array}$ & $\begin{array}{c}3700.30 \\
(98.11) \\
\end{array}$ & $\begin{array}{c}3960.06 \\
(91.18) \\
\end{array}$ & $\begin{array}{l}4622.41 \\
(119.55) \\
\end{array}$ & $\begin{array}{l}5660.76 \\
(181.48) \\
\end{array}$ \\
\hline & $\begin{array}{c}3 \\
\text { children } \\
\end{array}$ & $\begin{array}{c}3248.36 \\
(78.86) \\
\end{array}$ & $\begin{array}{l}4048.30 \\
(123.27) \\
\end{array}$ & $\begin{array}{l}4334.96 \\
(126.87) \\
\end{array}$ & $\begin{array}{l}4891.62 \\
(162.00) \\
\end{array}$ & $\begin{array}{l}5680.31 \\
(202.46) \\
\end{array}$ & $\begin{array}{r}3149.39 \\
(78.51) \\
\end{array}$ & $\begin{array}{l}4066.74 \\
(117.10) \\
\end{array}$ & $\begin{array}{l}4297.53 \\
(116.45) \\
\end{array}$ & $\begin{array}{l}4969.21 \\
(139.19) \\
\end{array}$ & $\begin{array}{l}6092.07 \\
(203.18) \\
\end{array}$ \\
\hline \multirow{4}{*}{3500} & $\begin{array}{c}\text { No } \\
\text { children }\end{array}$ & --- & $\begin{array}{r}4283.06 \\
(101.23)\end{array}$ & $\begin{array}{c}5106.26 \\
(96.35)\end{array}$ & $\begin{array}{l}5814.46 \\
(162.29)\end{array}$ & $\begin{array}{l}6676.81 \\
(246.29)\end{array}$ & --- & $\begin{array}{c}4540.70 \\
(94.02)\end{array}$ & $\begin{array}{c}5277.44 \\
(92.51)\end{array}$ & $\begin{array}{l}6135.82 \\
(139.01)\end{array}$ & $\begin{array}{l}7432.32 \\
(228.72)\end{array}$ \\
\hline & $\begin{array}{c}1 \\
\text { child }\end{array}$ & $\begin{array}{c}4098.56 \\
(51.18) \\
\end{array}$ & $\begin{array}{l}4992.76 \\
(126.82) \\
\end{array}$ & $\begin{array}{l}5695.85 \\
(128.51) \\
\end{array}$ & $\begin{array}{l}6403.61 \\
(185.71) \\
\end{array}$ & \begin{tabular}{|l|}
7385.56 \\
$(272.41)$ \\
\end{tabular} & $\begin{array}{l}3980.95 \\
(31.45) \\
\end{array}$ & $\begin{array}{l}5104.73 \\
(105.89) \\
\end{array}$ & $\begin{array}{l}5752.10 \\
(108.92) \\
\end{array}$ & \begin{tabular}{|l|}
6695.43 \\
$(157.54)$ \\
\end{tabular} & $\begin{array}{l}8077.59 \\
(246.22) \\
\end{array}$ \\
\hline & $\begin{array}{c}2 \\
\text { children } \\
\end{array}$ & $\begin{array}{c}4642.07 \\
(95.51) \\
\end{array}$ & $\begin{array}{l}5588.97 \\
(160.52) \\
\end{array}$ & $\begin{array}{l}6275.42 \\
(169.05) \\
\end{array}$ & $\begin{array}{l}6972.32 \\
(215.22) \\
\end{array}$ & $\begin{array}{l}8035.56 \\
(303.25) \\
\end{array}$ & $\begin{array}{r}4410.34 \\
(63.10) \\
\end{array}$ & $\begin{array}{l}5576.07 \\
(124.63) \\
\end{array}$ & $\begin{array}{l}6175.15 \\
(128.12) \\
\end{array}$ & $\begin{array}{l}7141.49 \\
(177.50) \\
\end{array}$ & $\begin{array}{l}8592.84 \\
(265.15) \\
\end{array}$ \\
\hline & $\begin{array}{c}3 \\
\text { children }\end{array}$ & $\begin{array}{l}5188.36 \\
(141.92)\end{array}$ & $\begin{array}{l}6210.34 \\
(207.81)\end{array}$ & $\begin{array}{l}6852.39 \\
(203.06)\end{array}$ & $\begin{array}{l}7574.81 \\
(257.13)\end{array}$ & $\begin{array}{l}8705.11 \\
(344.42)\end{array}$ & $\begin{array}{c}4815.52 \\
(94.54)\end{array}$ & $\begin{array}{c}6028.02 \\
(148.12)\end{array}$ & $\begin{array}{l}6594.02 \\
(155.18)\end{array}$ & $\begin{array}{l}7582.62 \\
(201.16)\end{array}$ & $\begin{array}{l}9100.91 \\
(285.35)\end{array}$ \\
\hline
\end{tabular}


Table 3. Stated NMTE-decrease compensations (values in Euros)

\begin{tabular}{|c|c|c|c|c|c|c|c|c|c|c|c|c|c|}
\hline \multicolumn{14}{|c|}{ Belgium } \\
\hline & & \multirow{2}{*}{\multicolumn{4}{|c|}{$\begin{array}{c}\text { Singles } \\
N \rightarrow W \\
\text { ctive reduction in NMTE) }\end{array}$}} & \multicolumn{8}{|c|}{ Couples } \\
\hline & & & & & & \multicolumn{4}{|c|}{$\begin{array}{c}\qquad N \mathrm{~W} \rightarrow W N \\
\text { (nonrestrictive reduction in } N M T E \text { ) }\end{array}$} & \multicolumn{4}{|c|}{$\begin{array}{c}W N \rightarrow W W \\
\text { (restrictive reduction in NMTE) }\end{array}$} \\
\hline$y_{r}$ & & $\begin{array}{c}\text { No } \\
\text { children }\end{array}$ & $\begin{array}{c}1 \\
\text { child }\end{array}$ & $\begin{array}{c}2 \\
\text { children }\end{array}$ & $\begin{array}{c}3 \\
\text { children }\end{array}$ & $\begin{array}{c}\text { No } \\
\text { children }\end{array}$ & $\begin{array}{c}1 \\
\text { child }\end{array}$ & $\begin{array}{c}2 \\
\text { children }\end{array}$ & $\begin{array}{c}3 \\
\text { children }\end{array}$ & $\begin{array}{c}\text { No } \\
\text { children }\end{array}$ & $\begin{array}{c}1 \\
\text { child }\end{array}$ & $\begin{array}{c}2 \\
2 \\
\text { children }\end{array}$ & $\begin{array}{c}3 \\
\text { children }\end{array}$ \\
\hline \multirow{5}{*}{500} & Mean & 303.34 & 331.49 & 357.58 & 381.45 & 261.11 & 259.02 & 263.63 & 255.78 & 309.67 & 372.20 & 400.44 & 429.07 \\
\hline & Median & 250.00 & 250.00 & 275.00 & 300.00 & 150.00 & 150.00 & 150.00 & 150.00 & 200.00 & 250.00 & 250.00 & 300.00 \\
\hline & Std.error & $(23.24)$ & (22.72) & (24.56) & (28.07) & (24.57) & $(25.26)$ & $(26.27)$ & $(23.50)$ & (28.30) & (31.17) & (34.94) & (39.73) \\
\hline & Wilcoxon & \multirow{2}{*}{\multicolumn{2}{|c|}{$\begin{array}{l}3.53^{* * * *} \\
{[0.00]}\end{array}$}} & \multirow{2}{*}{\multicolumn{2}{|c|}{$\begin{array}{l}2.78^{* * * *} \\
{[0.01]}\end{array}$}} & \multirow{2}{*}{\multicolumn{4}{|c|}{$\begin{array}{ccc}0.50 & 0.77 & 0.39 \\
{[0.62]} & {[0.44]} & {[0.70]}\end{array}$}} & \multirow{2}{*}{\multicolumn{4}{|c|}{$\begin{array}{ccc}5.41^{* * * *} & 3.18^{* * * *} & 4.01^{* * * *} \\
{[0.00]} & {[0.00]} & {[0.00]}\end{array}$}} \\
\hline & p-value & & & & & & & & & & & & \\
\hline \multirow{5}{*}{2000} & Mean & 621.05 & 692.49 & 740.68 & 799.94 & 471.11 & 501.89 & 514.56 & 556.66 & 610.21 & 700.61 & 749.95 & 788.68 \\
\hline & Median & 400.00 & 500.00 & 500.00 & 500.00 & 250.00 & 250.00 & 250.00 & 250.00 & 300.00 & 500.00 & 500.00 & 500.00 \\
\hline & Std.error & (64.76) & $(70.41)$ & $(75.30)$ & (81.77) & (61.94) & $(66.32)$ & (69.99) & $(84.01)$ & (68.70) & $(70.32)$ & $(73.10)$ & $(74.60)$ \\
\hline & Wilcoxon & \multirow{2}{*}{\multicolumn{2}{|c|}{$\begin{array}{l}4.31^{* * *+} \\
{[0.00]}\end{array}$}} & \multirow{2}{*}{\multicolumn{2}{|c|}{$\begin{array}{l}5.13^{\text {***** }} \\
{[0.00]}\end{array}$}} & \multirow{2}{*}{\multicolumn{2}{|c|}{$\begin{array}{c}1.93^{*} \\
{[0.05]}\end{array}$}} & \multirow{2}{*}{\multicolumn{2}{|c|}{$\begin{array}{l}2.69^{* * * * *} \\
{[0.01]}\end{array}$}} & \multirow{2}{*}{\multicolumn{4}{|c|}{$\begin{array}{ccc}6.20^{* * * *} & 4.31^{* * * *} & 4.52^{* * * *} \\
{[0.00]} & {[0.00]} & {[0.00]} \\
\end{array}$}} \\
\hline & p-value & & & & & & & & & & & & \\
\hline \multirow{5}{*}{3500} & Mean & 783.06 & 894.19 & 946.90 & 1021.98 & 708.19 & 707.77 & 696.90 & 722.42 & 862.36 & 981.95 & 1063.24 & 1130.31 \\
\hline & Median & 500.00 & 500.00 & 500.00 & 500.00 & 300.00 & 300.00 & 300.00 & 300.00 & 500.00 & 500.00 & 500.00 & 600.00 \\
\hline & Std.error & (101.23) & (105.82) & (110.61) & (118.70) & (107.56) & (106.56) & (105.83) & (109.54) & (107.45) & (116.76) & (126.65) & $(132.15)$ \\
\hline & Wilcoxon & \multirow{2}{*}{\multicolumn{2}{|c|}{$\begin{array}{c}6.40 \\
{[0.00]}\end{array}$}} & \multirow{2}{*}{\multicolumn{2}{|c|}{$\begin{array}{ll}1.25^{* * * *} & 3.90^{* * * * *} \\
0.00] & {[0.00]}\end{array}$}} & \multirow{2}{*}{\multicolumn{2}{|c|}{$\begin{array}{c}0.76 \\
{[0.45]}\end{array}$}} & \multirow{2}{*}{\multicolumn{2}{|c|}{$\begin{array}{lc}.94 & 0.28 \\
.34] & {[0.78]}\end{array}$}} & \multirow{2}{*}{\multicolumn{2}{|c|}{$\begin{array}{c}5.67^{* * * *} \\
{[0.00]}\end{array}$}} & \multirow{2}{*}{\multicolumn{2}{|c|}{$\begin{array}{l}5.15^{* * * \cdots} \\
{[0.00]}\end{array}$}} \\
\hline & $p$-value & & & & & & & & & & & & \\
\hline
\end{tabular}


Table 3 continued.

\begin{tabular}{|c|c|c|c|c|c|c|c|c|c|c|c|c|c|}
\hline \multicolumn{14}{|c|}{ Germany } \\
\hline & & \multirow{2}{*}{\multicolumn{4}{|c|}{$\begin{array}{c}\text { Singles } \\
N \rightarrow W \\
\text { tive reduction in NMTE) }\end{array}$}} & \multicolumn{8}{|c|}{ Couples } \\
\hline & & & & & & \multicolumn{4}{|c|}{$\begin{array}{c}\qquad N N \rightarrow W N \\
\text { (nonrestrictive reduction in } N M T E \text { ) }\end{array}$} & \multicolumn{4}{|c|}{$\begin{array}{c}W N \rightarrow W W \\
\text { (restrictive reduction in NMTE) }\end{array}$} \\
\hline$y_{r}$ & & $\begin{array}{c}\text { No } \\
\text { children }\end{array}$ & $\begin{array}{c}1 \\
\text { child }\end{array}$ & $\begin{array}{c}2 \\
\text { children }\end{array}$ & $\begin{array}{c}3 \\
\text { children }\end{array}$ & $\begin{array}{c}\text { No } \\
\text { children }\end{array}$ & $\begin{array}{c}1 \\
\text { child }\end{array}$ & $\begin{array}{c}2 \\
\text { children } \\
\end{array}$ & $\begin{array}{c}3 \\
\text { children } \\
\end{array}$ & $\begin{array}{c}\text { No } \\
\text { children }\end{array}$ & $\begin{array}{c}1 \\
\text { child }\end{array}$ & $\begin{array}{c}2 \\
\text { children } \\
\end{array}$ & $\begin{array}{c}3 \\
\text { children } \\
\end{array}$ \\
\hline \multirow{5}{*}{500} & Mean & 403.35 & 425.76 & 425.21 & 435.64 & 337.20 & 337.87 & 343.78 & 355.47 & 401.52 & 466.62 & 505.03 & 542.83 \\
\hline & Median & 312.50 & 350.00 & 350.00 & 350.00 & 250.00 & 250.00 & 250.00 & 250.00 & 250.00 & 300.00 & 325.00 & 350.00 \\
\hline & Std.error & $(21.66)$ & $(22.95)$ & $(25.48)$ & $(28.12)$ & $(24.85)$ & $(26.26)$ & $(28.15)$ & $(34.20)$ & $(29.06)$ & $(29.59)$ & (31.95) & (34.91) \\
\hline & Wilcoxon & \multirow{2}{*}{\multicolumn{2}{|c|}{$\begin{array}{l}2.26^{* *} \\
{[0.02]}\end{array}$}} & \multirow{2}{*}{\multicolumn{2}{|c|}{$\begin{array}{c}1.24 \\
{[0.21]}\end{array}$}} & \multirow{2}{*}{\multicolumn{4}{|c|}{$\begin{array}{ccc}0.97 & 0.91 & 0.67 \\
{[0.33]} & {[0.36]} & {[0.50]} \\
\end{array}$}} & \multirow{2}{*}{\multicolumn{2}{|c|}{$\begin{array}{l}7.01^{* * * 1} \\
{[0.00]}\end{array}$}} & \multirow{2}{*}{\multicolumn{2}{|c|}{$\begin{array}{l}4.92^{* * *} \\
{[0.00]}\end{array}$}} \\
\hline & p-value & & & & & & & & & & & & \\
\hline \multirow{5}{*}{2000} & Mean & 829.57 & 847.71 & 888.11 & 917.35 & 628.87 & 658.54 & 662.35 & 671.68 & 862.44 & 962.20 & 1038.35 & 1122.87 \\
\hline & Median & 500.00 & 500.00 & 500.00 & 500.00 & 500.00 & 500.00 & 500.00 & 500.00 & 500.00 & 575.00 & 625.00 & 750.00 \\
\hline & Std.error & $(67.48)$ & $(68.75)$ & (73.09) & (78.28) & (59.94) & $(63.23)$ & (64.58) & (65.14) & (86.14) & (91.39) & $(97.50)$ & (105.26) \\
\hline & Wilcoxon & \multirow{2}{*}{\multicolumn{2}{|c|}{$\begin{array}{l}4.22^{* * * *} \\
{[0.00]}\end{array}$}} & \multirow{2}{*}{\multicolumn{2}{|c|}{$\begin{array}{ll}4.03^{* * * *} & 3.36^{* * *} \\
{[0.00]} & {[0.00]}\end{array}$}} & \multirow{2}{*}{\multicolumn{4}{|c|}{$\begin{array}{ccc}2.96^{* * * *} & 1.23 & 1.83^{*} \\
{[0.00]} & {[0.22]} & {[0.07]} \\
\end{array}$}} & \multirow{2}{*}{\multicolumn{4}{|c|}{$\begin{array}{ccc}7.27^{* * * *} & 5.68^{* * * *} & 5.88^{* * *} \\
{[0.00]} & {[0.00]} & {[0.00]} \\
\end{array}$}} \\
\hline & p-value & & & & & & & & & & & & \\
\hline \multirow{5}{*}{3500} & Mean & 1040.70 & 1123.78 & 1165.73 & 1212.50 & 858.38 & 943.32 & 966.34 & 988.60 & \begin{tabular}{|l|}
1296.49 \\
\end{tabular} & 1382.16 & 1451.34 & 1518.29 \\
\hline & Median & 500.00 & 700.00 & 725.00 & 750.00 & 500.00 & 500.00 & 500.00 & 500.00 & 875.00 & 1000.00 & 1000.00 & 1000.00 \\
\hline & Std.error & 94.02) & (100.14) & (105.44) & (110.51) & (85.63) & (94.53) & (97.95) & (101.58) & (131.09) & (135.11) & (139.05) & $(142.21)$ \\
\hline & Wilcoxon & \multirow{2}{*}{\multicolumn{2}{|c|}{$\begin{array}{l}5.24^{* * *} \\
{[0.00]}\end{array}$}} & \multirow{2}{*}{\multicolumn{2}{|c|}{$\begin{array}{ll}3.97^{* * * *} & 4.93^{* * * *} \\
{[0.00]} & {[0.00]}\end{array}$}} & \multirow{2}{*}{\multicolumn{2}{|c|}{$\begin{array}{l}3.97^{* * * *} \\
{[0.00]}\end{array}$}} & \multirow{2}{*}{\multicolumn{2}{|c|}{$\begin{array}{lc}2.28^{* * *} & 2.70^{* * * *} \\
{[0.02]} & {[0.01]}\end{array}$}} & \multirow{2}{*}{\multicolumn{3}{|c|}{$\begin{array}{cc}5.78^{* * * *} & 5.44^{* * * *} \\
{[0.00]} & {[0.00]} \\
\end{array}$}} & \multirow{2}{*}{$\begin{array}{l}\frac{1}{4.57^{* * 2.21}} \\
0.00]\end{array}$} \\
\hline & $p$-value & & & & & & & & & & & & \\
\hline
\end{tabular}


Table 4. Regressions for estimating child costs

\begin{tabular}{|c|c|c|c|c|c|c|c|c|c|c|c|c|c|}
\hline \multicolumn{14}{|c|}{ Belgium } \\
\hline \multirow{2}{*}{\multicolumn{2}{|c|}{$\mathbf{y}_{\mathbf{r}}$}} & \multicolumn{4}{|c|}{$y_{r}=500$} & \multicolumn{4}{|c|}{$y_{r}=2000$} & \multicolumn{4}{|c|}{$y_{r}=3500$} \\
\hline & & Spec. 1 & Spec. 2 & Spec. 3 & Spec. 4 & Spec. 1 & Spec. 2 & Spec. 3 & Spec. 4 & Spec. 1 & Spec. 2 & Spec. 3 & Spec. 4 \\
\hline $\boldsymbol{\alpha}_{\mathbf{y}}$ & $n_{C}$ & $\begin{array}{c}0.67^{\star * \star} \\
(0.03)\end{array}$ & $\begin{array}{c}0.59^{\star * *} \\
(0.03)\end{array}$ & $\begin{array}{c}0.57^{\star \star \star} \\
(0.03)\end{array}$ & $\begin{array}{c}0.59^{\star \star *} \\
(0.03)\end{array}$ & $\begin{array}{c}0.44^{\star \star \star} \\
(0.03)\end{array}$ & $\begin{array}{c}0.37^{\star * *} \\
(0.03)\end{array}$ & $\begin{array}{c}0.35^{\star \star \star} \\
(0.03)\end{array}$ & $\begin{array}{c}0.36^{\star \star \star} \\
(0.03)\end{array}$ & $\begin{array}{c}0.39^{\star \star \star} \\
(0.03)\end{array}$ & $\begin{array}{c}0.34^{\star \star *} \\
(0.03)\end{array}$ & $\begin{array}{c}0.32^{\star \star *} \\
(0.03)\end{array}$ & $\begin{array}{c}0.33^{* * *} \\
(0.03)\end{array}$ \\
\hline $\boldsymbol{\beta}_{\mathbf{y}}$ & $n_{W}$ & $\begin{array}{c}0.91^{\star \star \star} \\
(0.05)\end{array}$ & $\begin{array}{c}0.75^{\star \star \star} \\
(0.06)\end{array}$ & & & $\begin{array}{c}0.64^{\star * *} \\
(0.05)\end{array}$ & $\begin{array}{l}0.51^{\star \star *} \\
(0.06)\end{array}$ & & & $\begin{array}{c}0.57^{* * *} \\
(0.05)\end{array}$ & $\begin{array}{c}0.48^{* * *} \\
(0.06)\end{array}$ & & \\
\hline$\gamma_{\mathbf{y}}$ & $n_{C} \cdot D_{W N}$ & & $\begin{array}{l}-0.03 \\
(0.04)\end{array}$ & $\begin{array}{c}0.03 \\
(0.05)\end{array}$ & $\begin{array}{c}0.06 \\
(0.06)\end{array}$ & & $\begin{array}{c}0.01 \\
(0.05)\end{array}$ & $\begin{array}{c}0.08 \\
(0.06)\end{array}$ & $\begin{array}{l}0.13^{*} \\
(0.07)\end{array}$ & & $\begin{array}{l}-0.01 \\
(0.05)\end{array}$ & $\begin{array}{c}0.05 \\
(0.07) \\
\end{array}$ & $\begin{array}{c}0.10 \\
(0.08)\end{array}$ \\
\hline $\boldsymbol{\delta}_{\mathbf{y}}$ & $n_{C} \cdot D_{F}$ & & $\begin{array}{c}0.11^{* * *} \\
(0.04)\end{array}$ & $\begin{array}{c}0.11^{* * *} \\
(0.04)\end{array}$ & & & $\begin{array}{l}0.11^{* \star *} \\
(0.04)\end{array}$ & $\begin{array}{c}0.11^{* * *} \\
(0.04)\end{array}$ & & & $\begin{array}{c}0.07 \\
(0.05)\end{array}$ & $\begin{array}{c}0.07 \\
(0.05)\end{array}$ & \\
\hline$\zeta_{\mathrm{y}}$ & $n_{A} \cdot D_{W N}$ & & & $\begin{array}{c}0.30^{\star \star \star} \\
(0.04)\end{array}$ & $\begin{array}{c}0.32^{\star \star \star} \\
(0.05)\end{array}$ & & & $\begin{array}{c}0.17^{\star \star \star} \\
(0.03)\end{array}$ & $\begin{array}{c}0.18^{\star \star \star} \\
(0.05)\end{array}$ & & & $\begin{array}{c}0.16^{\star \star \star} \\
(0.05)\end{array}$ & $\begin{array}{c}0.18^{\star \star \star *} \\
(0.06)\end{array}$ \\
\hline$\eta_{\mathbf{y}}$ & $n_{A} \cdot D_{F}$ & & & $\begin{array}{c}0.74^{\star * *} \\
(0.06)\end{array}$ & & & & $\begin{array}{c}0.51^{* * *} \\
(0.05)\end{array}$ & & & & $\begin{array}{c}0.48^{* * *} \\
(0.06)\end{array}$ & \\
\hline$\varphi_{\mathrm{y}}$ & $n_{C} \cdot D_{W}$ & & & & $\begin{array}{l}0.10^{\star *} \\
(0.05)\end{array}$ & & & & $\begin{array}{l}0.10^{\star *} \\
(0.05) \\
\end{array}$ & & & & $\begin{array}{c}0.07 \\
(0.06)\end{array}$ \\
\hline$\chi_{y}$ & $n_{C} \cdot D_{W W}$ & & & & $\begin{array}{l}0.20^{* *} \\
(0.09)\end{array}$ & & & & $\begin{array}{l}0.24^{* *} \\
(0.11)\end{array}$ & & & & $\begin{array}{c}0.22^{*} \\
(0.12)\end{array}$ \\
\hline$\psi_{\mathbf{y}}$ & $n_{A} \cdot D_{W}$ & & & & $\begin{array}{c}0.75^{\star \star *} \\
(0.06)\end{array}$ & & & & $\begin{array}{c}0.48^{* * *} \\
(0.07)\end{array}$ & & & & $\begin{array}{c}0.42^{\star * *} \\
(0.08)\end{array}$ \\
\hline$\omega_{\mathrm{y}}$ & $n_{A} \cdot D_{W W}$ & & & & $\begin{array}{c}0.77^{\star * \star} \\
(0.06)\end{array}$ & & & & $\begin{array}{l}0.51^{* * *} \\
(0.08)\end{array}$ & & & & $\begin{array}{l}0.49^{\star \star \star} \\
(0.09)\end{array}$ \\
\hline$\theta_{\mathbf{y}}$ & & $\begin{array}{c}0.85^{\star \star *} \\
(0.02)\end{array}$ & $\begin{array}{c}0.88^{\star \star \star} \\
(0.02)\end{array}$ & $\begin{array}{c}0.88^{\star \star \star} \\
(0.02)\end{array}$ & $\begin{array}{c}0.85^{\star \star \star} \\
(0.02)\end{array}$ & $\begin{array}{c}0.68^{\star \star \star} \\
(0.02)\end{array}$ & $\begin{array}{c}0.69^{\star \star \star} \\
(0.02)\end{array}$ & $\begin{array}{c}0.70^{\star * \star} \\
(0.02)\end{array}$ & $\begin{array}{c}0.66^{* \star *} \\
(0.03)\end{array}$ & $\begin{array}{c}0.63^{\star * \star} \\
(0.02)\end{array}$ & $\begin{array}{c}0.64^{* \star \star} \\
(0.02)\end{array}$ & $\begin{array}{c}0.64^{* \star \star} \\
(0.02)\end{array}$ & $\begin{array}{c}0.59^{\star \star *} \\
(0.03)\end{array}$ \\
\hline & $\bar{R}^{2}$ & 0.44 & 0.44 & 0.44 & 0.44 & 0.32 & 0.32 & 0.32 & 0.33 & 0.31 & 0.31 & 0.31 & 0.31 \\
\hline
\end{tabular}


Table 4 continued.

\begin{tabular}{|c|c|c|c|c|c|c|c|c|c|c|c|c|c|}
\hline \multicolumn{14}{|c|}{ Germany } \\
\hline \multirow{2}{*}{\multicolumn{2}{|c|}{$\mathbf{y}_{\mathbf{r}}$}} & \multicolumn{4}{|c|}{$y_{r}=500$} & \multicolumn{4}{|c|}{$y_{r}=2000$} & \multicolumn{4}{|c|}{$y_{r}=3500$} \\
\hline & & Spec. 1 & Spec. 2 & Spec. 3 & Spec. 4 & Spec. 1 & Spec. 2 & Spec. 3 & Spec. 4 & Spec. 1 & Spec. 2 & Spec. 3 & Spec. 4 \\
\hline $\boldsymbol{\alpha}_{\mathrm{y}}$ & $n_{C}$ & $\begin{array}{c}0.64^{\star * *} \\
(0.03)\end{array}$ & $\begin{array}{c}0.57^{\star \star *} \\
(0.03)\end{array}$ & $\begin{array}{c}0.55^{\star \star *} \\
(0.03)\end{array}$ & $\begin{array}{c}0.58^{\star \star \star} \\
(0.03)\end{array}$ & $\begin{array}{c}0.36^{\star * *} \\
(0.02)\end{array}$ & $\begin{array}{l}0.32^{\star * *} \\
(0.02)\end{array}$ & $\begin{array}{c}0.30^{\star * *} \\
(0.02)\end{array}$ & $\begin{array}{c}0.30^{\star \star \star} \\
(0.02)\end{array}$ & $\begin{array}{c}0.26^{\star \star *} \\
(0.02)\end{array}$ & $\begin{array}{c}0.23^{\star \star \star} \\
(0.02)\end{array}$ & $\begin{array}{c}0.21^{* \star *} \\
(0.02)\end{array}$ & $\begin{array}{c}0.19^{\star \star \star} \\
(0.02)\end{array}$ \\
\hline $\boldsymbol{\beta}_{\mathbf{y}}$ & $n_{W}$ & $\begin{array}{c}0.95^{* * *} \\
(0.04)\end{array}$ & $\begin{array}{c}0.82^{* * *} \\
(0.05)\end{array}$ & & & $\begin{array}{c}0.77^{* \star \star} \\
(0.05)\end{array}$ & $\begin{array}{c}0.66^{\star \star *} \\
(0.06)\end{array}$ & & & $\begin{array}{c}0.68^{\star \star *} \\
(0.04)\end{array}$ & $\begin{array}{c}0.59^{* * *} \\
(0.05)\end{array}$ & & \\
\hline$\gamma_{\mathbf{y}}$ & $n_{C} \cdot D_{W N}$ & & $\begin{array}{l}-0.03 \\
(0.04)\end{array}$ & $\begin{array}{c}0.02 \\
(0.05)\end{array}$ & $\begin{array}{c}0.05 \\
(0.05)\end{array}$ & & $\begin{array}{c}-0.04 \\
(0.04)\end{array}$ & $\begin{array}{c}0.03 \\
(0.05)\end{array}$ & $\begin{array}{c}0.07 \\
(0.06)\end{array}$ & & $\begin{array}{l}-0.03 \\
(0.04)\end{array}$ & $\begin{array}{c}0.07 \\
(0.05)\end{array}$ & $\begin{array}{c}0.18^{\star \star \star} \\
(0.07)\end{array}$ \\
\hline $\boldsymbol{\delta}_{\mathbf{y}}$ & $n_{C} \cdot D_{F}$ & & $\begin{array}{c}0.08^{* * *} \\
(0.03)\end{array}$ & $\begin{array}{l}0.08^{* *} \\
(0.03)\end{array}$ & & & $\begin{array}{c}0.07^{*} \\
(0.04)\end{array}$ & $\begin{array}{l}0.07^{*} \\
(0.04)\end{array}$ & & & $\begin{array}{l}0.06^{*} \\
(0.03)\end{array}$ & $\begin{array}{l}0.06^{*} \\
(0.03)\end{array}$ & \\
\hline$\zeta_{\mathbf{y}}$ & $n_{A} \cdot D_{W N}$ & & & $\begin{array}{c}0.34^{* \star *} \\
(0.04)\end{array}$ & $\begin{array}{c}0.37^{\star \star *} \\
(0.04)\end{array}$ & & & $\begin{array}{c}0.24^{\star \star *} \\
(0.04)\end{array}$ & $\begin{array}{c}0.27^{\star \star \star} \\
(0.05)\end{array}$ & & & $\begin{array}{c}0.18^{\star \star \star} \\
(0.04)\end{array}$ & $\begin{array}{c}0.21^{\star \star \star} \\
(0.05)\end{array}$ \\
\hline$\eta_{\mathbf{y}}$ & $n_{A} \cdot D_{F}$ & & & $\begin{array}{c}0.81^{* * *} \\
(0.05)\end{array}$ & & & & $\begin{array}{c}0.66^{\star * *} \\
(0.05)\end{array}$ & & & & $\begin{array}{c}0.58^{\star * *} \\
(0.05)\end{array}$ & \\
\hline$\varphi_{\mathbf{y}}$ & $n_{C} \cdot D_{W}$ & & & & $\begin{array}{l}0.09^{* *} \\
(0.04)\end{array}$ & & & & $\begin{array}{c}0.07 \\
(0.05) \\
\end{array}$ & & & & $\begin{array}{c}0.12^{\star \star \star} \\
(0.04) \\
\end{array}$ \\
\hline$\chi_{y}$ & $n_{C} \cdot D_{W W}$ & & & & $\begin{array}{l}0.18^{* *} \\
(0.07)\end{array}$ & & & & $\begin{array}{l}0.20^{* *} \\
(0.09)\end{array}$ & & & & $\begin{array}{c}0.30^{* * *} \\
(0.11)\end{array}$ \\
\hline$\psi_{\mathbf{y}}$ & $n_{A} \cdot D_{W}$ & & & & $\begin{array}{c}0.80^{\star * \star} \\
(0.06)\end{array}$ & & & & $\begin{array}{c}0.62^{* \star *} \\
(0.07)\end{array}$ & & & & $\begin{array}{c}0.40^{\star \star *} \\
(0.07)\end{array}$ \\
\hline$\omega_{\mathrm{y}}$ & $n_{A} \cdot D_{W W}$ & & & & $\begin{array}{c}0.86^{\star * *} \\
(0.07)\end{array}$ & & & & $\begin{array}{c}0.70^{* * *} \\
(0.08)\end{array}$ & & & & $\begin{array}{c}0.71^{\star * *} \\
(0.10)\end{array}$ \\
\hline $\boldsymbol{\theta}_{\mathbf{y}}$ & & $\begin{array}{c}0.93^{* \star \star} \\
(0.02)\end{array}$ & $\begin{array}{c}0.96^{\star \star \star} \\
(0.02)\end{array}$ & $\begin{array}{c}0.96^{\star \star \star} \\
(0.02)\end{array}$ & $\begin{array}{c}0.92^{\star \star \star} \\
(0.02)\end{array}$ & $\begin{array}{c}0.72^{\star \star \star} \\
(0.02)\end{array}$ & $\begin{array}{c}0.74^{\star \star \star} \\
(0.02)\end{array}$ & $\begin{array}{c}0.75^{\star \star \star} \\
(0.02)\end{array}$ & $\begin{array}{c}0.70^{* \star *} \\
(0.02)\end{array}$ & $\begin{array}{c}0.66^{\star \star \star} \\
(0.01)\end{array}$ & $\begin{array}{c}0.68^{\star * \star} \\
(0.02)\end{array}$ & $\begin{array}{c}0.68^{\star * \star} \\
(0.02)\end{array}$ & $\begin{array}{c}0.58^{\star \star *} \\
(0.02)\end{array}$ \\
\hline & $\bar{R}^{2}$ & 0.53 & 0.53 & 0.53 & 0.53 & 0.38 & 0.38 & 0.38 & 0.38 & 0.37 & 0.37 & 0.37 & 0.37 \\
\hline 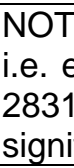 & Reg & $s$ for $\epsilon$ & refer & incom & deno & eff & e-inc & evel i & OS). & enous & able: & $\begin{array}{l}\text { valent-inc } \\
\text { er of ob } \\
\text { theses; }\end{array}$ & $\begin{array}{l}\text { me ratio } \\
\text { ervations } \\
\text { denotes }\end{array}$ \\
\hline
\end{tabular}


Table 5. Child costs relative to an adult in $W N$ vs. $W W$ households

\begin{tabular}{|c|c|c|c|c|c|c|}
\hline \multirow{3}{*}{$\mathrm{y}_{\mathrm{r}}$} & \multicolumn{4}{|c|}{ Spec. 4} & \multirow{2}{*}{\multicolumn{2}{|c|}{ Apps \& Rees (2001) }} \\
\hline & \multicolumn{2}{|c|}{ Belgium } & \multicolumn{2}{|c|}{ Germany } & & \\
\hline & $W N$ & $W W$ & $W N$ & $W W$ & $W N$ (average income) & $W W$ (average income) \\
\hline Poor (500) & 0.59 & 0.79 & 0.58 & 0.76 & \multirow{3}{*}{$\begin{array}{l}0.24-0.40^{\mathrm{a}} \\
0.82-0.98^{\mathrm{b}}\end{array}$} & \multirow{3}{*}{$\begin{array}{l}0.53-0.69^{\mathrm{a}} \\
0.78-0.91^{\mathrm{b}}\end{array}$} \\
\hline Middle (2000) & 0.36 & 0.60 & 0.30 & 0.50 & & \\
\hline rich (3500) & 0.33 & 0.55 & 0.37 & 0.49 & & \\
\hline
\end{tabular}




\section{Belgium}
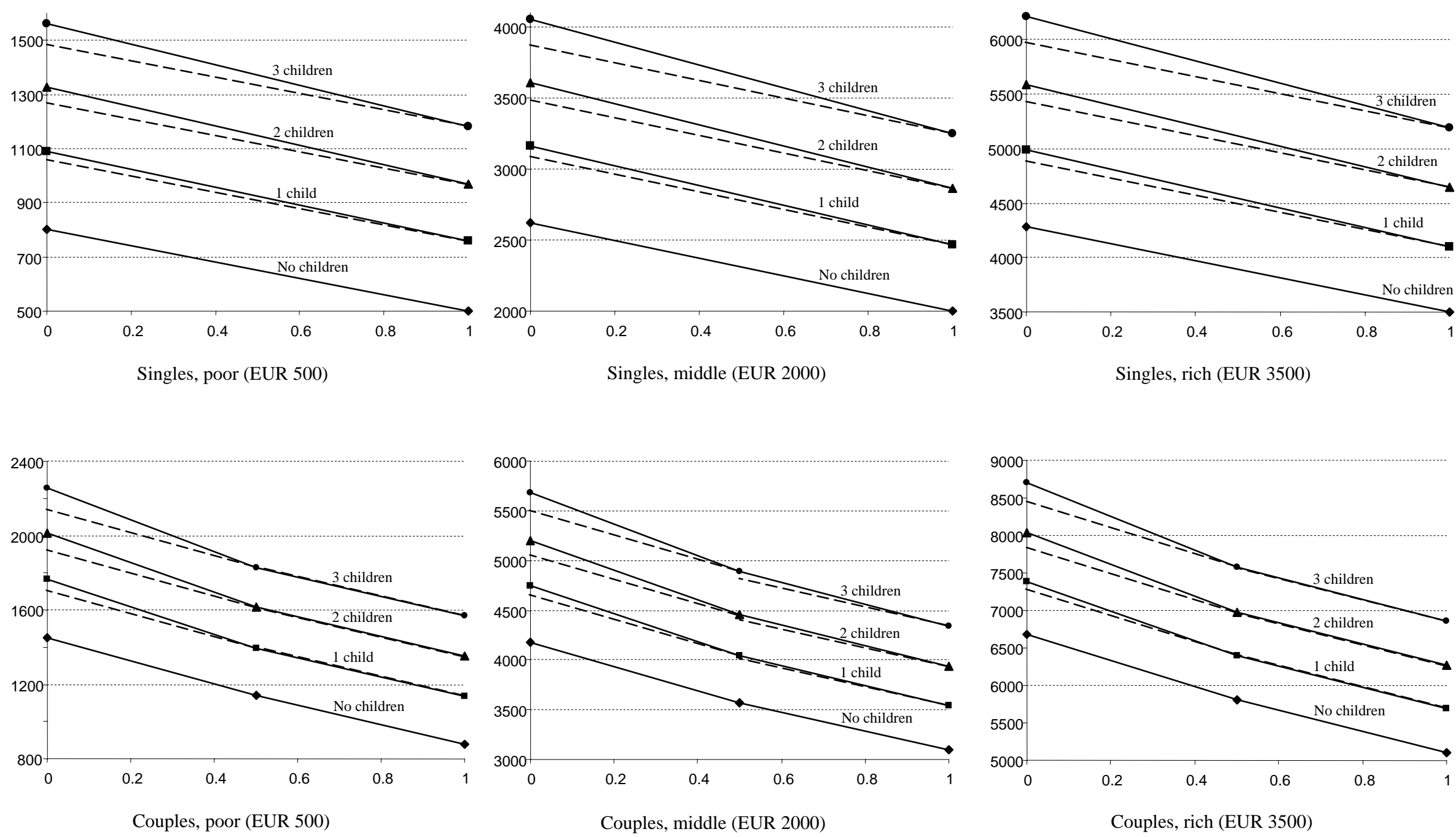


\section{Germany}

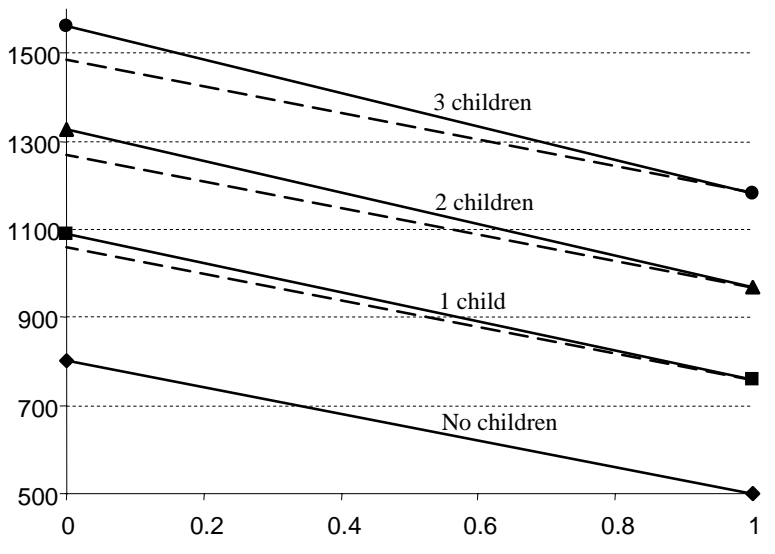

Singles, poor (EUR 500)

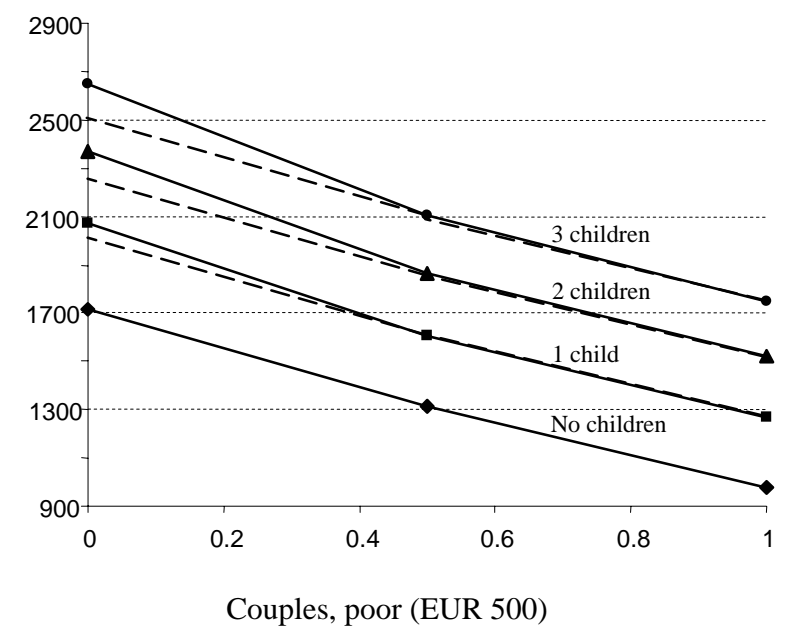

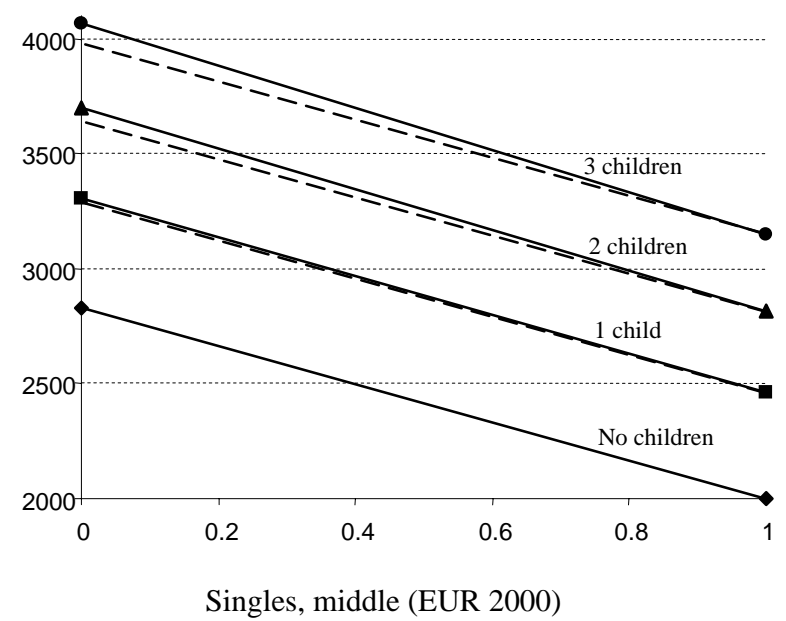

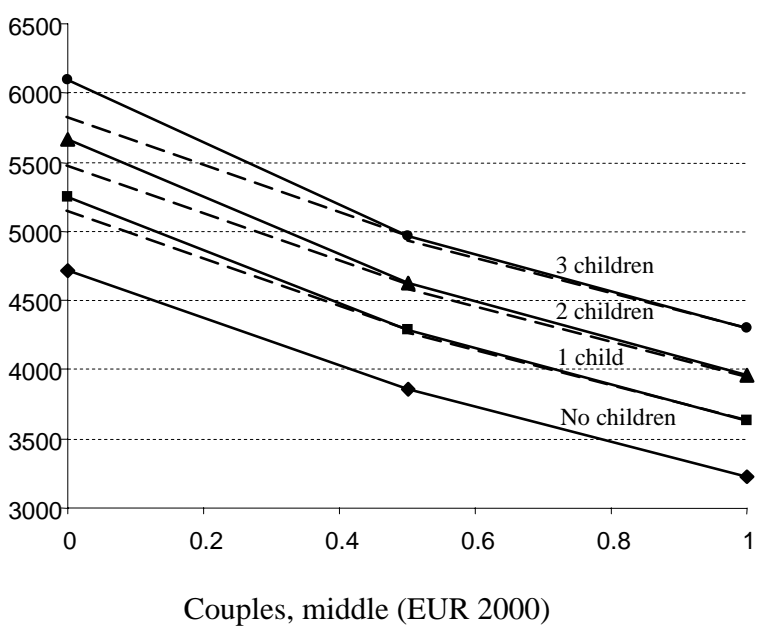

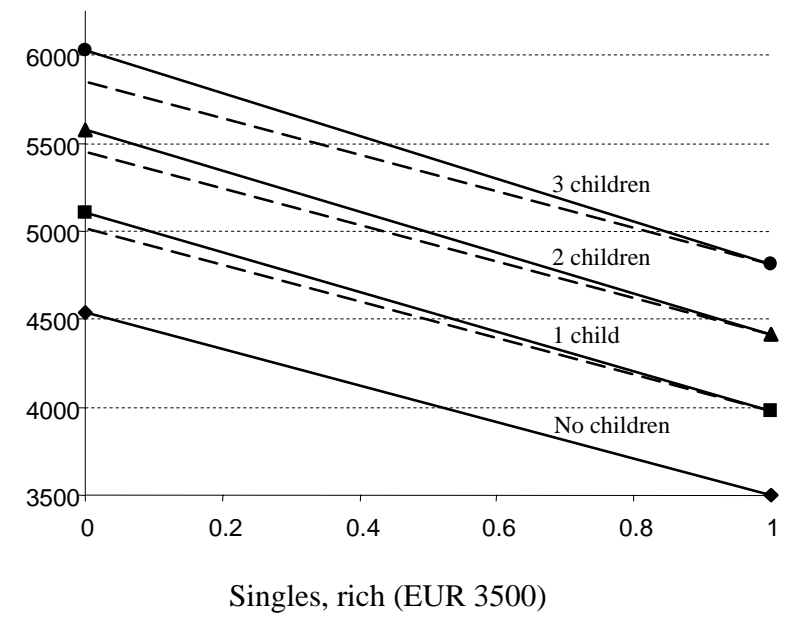

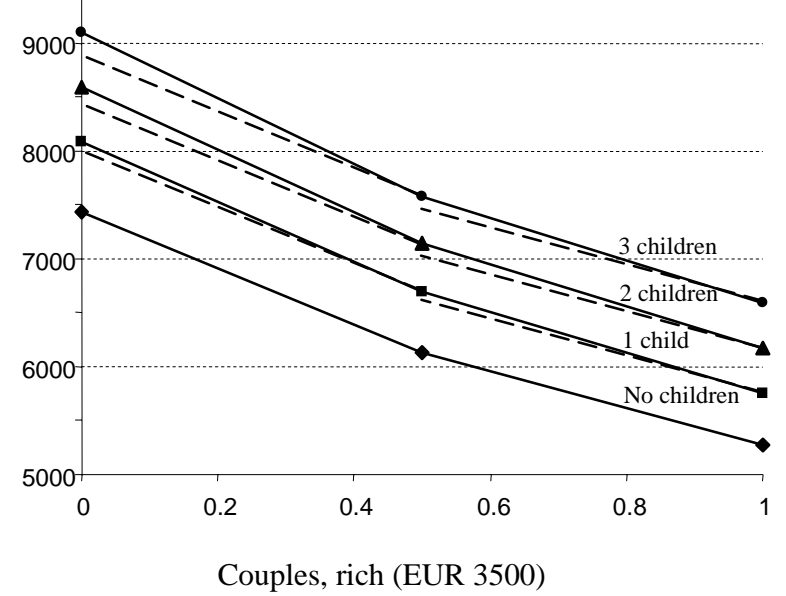

Figure 1. Equivalent incomes as functions of non-market time endowments. In each of the twelve graphs the dashed lines are the "No children" lines shifted upwards in a parallel manner in order to stress the change in the time/money tradeoff due to the presence of children. Reference incomes appear in parentheses. 


\section{Appendix}

\section{Survey instrument documentation}

\section{Purpose of the survey}

In general, different household types may need different income amounts in order to attain a given living standard. These income amounts may depend on the number of adults and children living in the household. Furthermore, household needs may depend on the labor-marketparticipation status of the adults (nonworking or working full time) since this might affect, for example, the time adults can spend for cooking or educating their children. Therefore, the following question arises:

Given the income of a specific household type (reference household), what is the income that can make another household type (that differs with respect to the number of children and/or adults and/or number of working adults) attain an identical living standard as the reference household?

Since there does not exist an objectively correct answer, we would like to know your subjective assessment of this question.

\section{Personal characteristics}

We would like to ask you to state some of your own personal characteristics. Please mark the boxes that apply to you. Your answers will be treated confidentially and only for the stated research purpose.

1) Please state your gender:

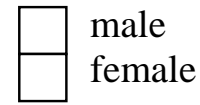

2) Are you living together with a partner?

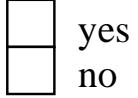

2a) In case your answer to question 2) is "yes:" Is your partner working

not at all part time full time irregularly?

3) How many children live in your household?

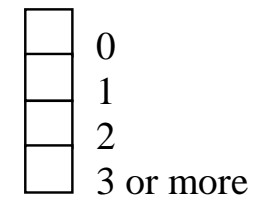

4) What is your after-tax family income per month?

below $1.75 \mathrm{P}^{*}$

$1.75 \mathrm{P}-3.25 \mathrm{P}$

$3.25 \mathrm{P}-4.75 \mathrm{P}$

$4.75 \mathrm{P}-6.25 \mathrm{P}$

6.25P and above

( *Note to researcher: $P$ is the "poverty line" in a country (see Section 2 for details).) 
5) Are you

social-security recipient unemployed blue-collar worker white-collar worker civil servant pupil, student, or trainee self-employed pensioner houseman/wife?

6) Are you working

not at all part-time full-time irregularly?

7) Please state your education level:

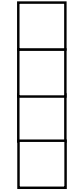

no degree elementary school secondary school technical school or university

8) Please state the number of siblings you lived together with during your childhood:

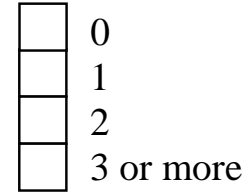

9) Please mark the correct age category you belong to:

below 20 years 20 - 40 years 40 years and older

\section{Income assessment}

In the tables below you shall evaluate three different situations. These situations differ by the prespecified after-tax monthly income (including all social transfers) of a nonworking-singlechildless-adult household. Now consider, for each situation separately, that the size and composition of the households change as indicated in the table.

Below, we give you an example of such a table. Please take some time to familiarize yourself with the structure of the table. 


\begin{tabular}{|l|l|l|l|l|l|}
\hline & $\begin{array}{l}1 \text { adult, } \\
\text { nonworking }\end{array}$ & $\begin{array}{l}1 \text { adult, } \\
\text { working full } \\
\text { time }\end{array}$ & $\begin{array}{l}2 \text { adults, } \\
\text { both } \\
\text { nonworking }\end{array}$ & $\begin{array}{l}2 \text { adults, } \\
1 \text { nonworking, } \\
1 \text { working full } \\
\text { time }\end{array}$ & $\begin{array}{l}\text { 2 adults, } \\
\text { both working } \\
\text { full time }\end{array}$ \\
\hline 0 children & $\begin{array}{l}\text { Reference } \\
\text { income }\end{array}$ & & & & \\
\hline 1 child & & & & & \\
\hline 2 children & & & & & \\
\hline 3 children & & & & & \\
\hline
\end{tabular}

Within a given table, all household types should attain the same living standard. Please, fill in the cells putting the after-tax/transfer family income that you believe brings the households that differ with respect to the numbers of children, adults, and working adults, to the same living standard as the one of the nonworking single childless adult.

Please, complete the following three tables. For your assessment assume that adults are between 35 and 55 and children between 7 and 11 years old.

(Note to researcher: In the actual survey three tables having the same structure as above were provided, each for a different reference income in increasing order.) 